Metallophysics and Advanced Technologies

Металофіз. новітні технол.

Metallofiz. Noveishie Tekhnol.

2021, vol. 43, No. 7, pp. 925-937

https://doi.org/10.15407/mfint.43.07.0925

Reprints available directly from the publisher
(C) 2021 G. V. Kurdyumov Institute for Metal Physics, National Academy of Sciences of Ukraine Published by license under the G. V. Kurdyumov Institute for Metal PhysicsN.A.S. of Ukraine Publishers imprint. Printed in Ukraine.

PACSnumbers: 61.72.Mm, 62.20.M-, 81.16.Mk, 81.20.Ev, 81.40.Ef, 81.40.Np, 81.70.Bt

\title{
Investigation of Mechanical Properties and Structure of Inconel 718 Alloy Obtained by Selective Laser Sintering from Powder Produced by 'LPW'
}

\author{
O. S. Vodennikova, M. O. Koval*, and S. A. Vodennikov*** \\ Zaporizhzhya National University, \\ 66 Zhukovsky Str., \\ UA-69600, Zaporizhzhya, Ukraine \\ "Motor Sich JSC, \\ 15 Motorostroiteley Ave., \\ UA-69068 Zaporizhzhya, Ukraine \\ *:Zaporizhzhia Polytechnic National University, \\ 64 Zhukovsky Str., \\ UA-69063 Zaporizhzhya, Ukraine
}

Modern aspects of high-quality product creating, made of Inconel 718 alloy, with the help of additive technologies are analysed. The possibility of manufacturing blanks by 3D-printing with heat-resistant Inconel 718 nickel alloy on the of direct laser sintering 'EOS M400' installation is tested. Technological indicators of hot isostatic pressing (HIP) operation using the subsequent heat treatment are given. A comparative analysis of the mechanical and heat-resistant properties of the Inconel 718 alloy, obtained by the method of selective laser sintering (SLS) from powders of the company 'LPW' (Great Britain), with the regulatory characteristics of ASM 5662M and TU 14-13905-85 is conducted. The dependence of mechanical properties (ultimate stress, $0.2 \%$ proof stress, relative extension, toughness, Young's modulus and Brinell hardness) of Inconel 718 alloy on the growth direction of the part (horizontal direction $X Y$ and vertical direction $Z$ ). The state of fractures after fracture of impact and impact specimens from Inconel 718 alloy, grown in both horizontal and vertical directions, is studied, and it is found that their structure is fine-grained. As shown, on the samples grown in the

Corresponding author: Oksana Vodennikova

E-mail: oksana_vodennikova@ukr.net

Citation: O. S. Vodennikova, M. O. Koval, and S. A. Vodennikov, Investigation of Mechanical Properties and Structure of Inconel 718 Alloy Obtained by Selective Laser Sintering from Powder Produced by 'LPW', Metallofiz. Noveishie Tekhnol., 43, No. 7: 925-937 (2021), DOI: 10.15407/mfint.43.07.0925. 
$X Y$ direction, the structural orientation is traced on the fractures (longitudinal section). The macrostructure of samples grown in both horizontal and vertical directions by the SLS method from Inconel 718 alloy is analysed. As shown, after the heat treatment operation it is possible to obtain a dense, homogeneous macrostructure samples characterized by a fine-grained structure with the presence of macrograins, which are elongated in the direction of growth of the sample. Metallographic studies have shown that the operation of the HIP followed by heat treatment contributes to almost complete 'healing' of pores and microdiscontinuities, which are concentrated in the internal volumes of the metal, while in the 'healing' areas the globular and (or) film oxides are found.

Key words: heat-resistant nickel alloy Inconel 718, selective laser sintering, additive technologies, mechanical and heat-resistant properties.

Проаналізовано сучасні аспекти створення якісних виробів зі стопу Inconel 718 за допомогою адитивних технологій. Проведено перевірку можливості виготовлення заготовок методом 3D-друку на установці прямого лазерного спікання «EOS M400» з жароміцного нікелевого стопу Inconel 718. Надано технологічні показники операції гарячого ізостатичного пресування (ГІП) з наступною термообробкою. Виконано порівняльний аналіз механічних та жароміцних властивостей стопу Inconel 718, одержаного методом селективного лазерного спікання (SLS) з порошку фірми «LPW» (Великобританія), з нормативними характеристиками ASM 5662M та TУ 14-1-3905-85. Встановлено залежність механічних властивостей (границі міцності, умовної границі плинності, відносного подовження, відносного звуження, ударної в'язкості, модуля пружності та твердості за Брінеллем) стопу Inconel 718 від напрямку зростання деталі (горизонтального напрямку $X Y$ та вертикального напрямку $Z$ ). Вивчено стан зламів після руйнування розривних та ударних зразків зі стопу Inconel 718, вирощених як у горизонтальному, так і у вертикальному напрямках, та встановлено, що їхня будова дріброзеренна. Показано, що на зразках, вирощених у напрямку $X Y$, на зламах (повздовжній перетин) простежується структурна напрямленість. Проаналізовано макроструктуру зразків, вирощених як у горизонтальному, так і у вертикальному напрямках методом SLS зі стопу Inconel 718. Показано, що після операції термообробки можливо отримати щільну, однорідну макроструктуру зразків, що характеризуеться дрібнозеренною будовою з наявністю макрозерен, які витягнуті у напрямку зростання зразка. Металографічними дослідженнями встановлено, що проведення операції ГІП з наступною термообробкою сприяє практично повному «заліковуванню» пір та мікронесуцільностей, які зосереджені у внутрішніх об'ємах металу, водночас у зонах «заліковування» виявлено глобулярні та (або) плівкові окисли.

Ключові слова: жароміцний нікелевий стоп Inconel 718 , селективне лазерне спікання, адитивні технології, механічні та жароміцні властивостi.

(Received March 24, 2021) 


\section{INTRODUCTION}

Today, the use of additive technologies is becoming increasingly used for the needs of the aviation and aerospace industry in the production and repair of turbine blades, fuel tanks, combustion chamber parts and other metal structures [1-3].

In particular, selective laser melting (SLM) technology, selective laser sintering (SLS) technology, and direct laser sintering (DMLS) technology have been widely used in 3D-printing [4]. 3D-printing of metal structures and parts using additive technologies, compared to traditional production processes, reduces the number of operations required for their manufacture, reduce waste, improve the quality of parts and reduce their weight [5], allows you to create parts with a geometry that ensures the ease of construction while maintaining high strength characteristics [6]. This will lead to significant savings in time and money [7].

Heat-resistant Inconel 718 alloy has been widely used in gas turbines, jet engines, nuclear reactors, high-pressure vessels due to the high stability of its mechanical properties at elevated temperatures (up to $800^{\circ} \mathrm{C}$ ) [8]. Thus, in [9] the application of additive technologies for the production of a combustion chamber of a rocket engine made of Inconel 718 alloy is considered.

The possibility of creating high-quality products from Inconel 718 alloy by SLM method at the installation of LLC 'Additive Laser Technology of Ukraine' is considered in [10]. The authors show the relationship between process parameters and microstructure, which necessitates the development of reasonable modes of SLM process for products for different purposes. In [11], a comprehensive study of the SLM process of the Inconel 718 alloy is performed. In particular, the results of the study of the morphology of particle size distribution, structure and phase composition of the nickel alloy powder, obtained by gas atomization of the melt, are represented.

The microstructure of the Inconel 718 alloy fabricated by the SLM method is also studied in [12]. It is shown that during fabrication multiple heating and cooling cycles formed a complex microheterogeneous structure, with chemical analysis showing high homogeneity. The work [13] is devoted to the study of the effect of laser radiation power on the microstructure and properties of samples from Inconel 738 alloy obtained by using SLM. The studies [14], which show the results of a comparative study of samples made by using the SLM method of powders of Inconel 718 alloy are of great interest. The powders are obtained by the method of gas automation of the melt with inert gas and centrifugal plasma spraying of a rapidly rotating rod blank. In [15], a comparative study of the structure and properties of samples after a separate hot isostatic pressing, a separate heat treatment, as well as 
after the HIP followed by heat treatment characteristic of the Inconel 718 alloy.

According to the work of [16] it is shown that the optimization of the modes of layered laser sintering with subsequent heat treatment of products allows to achieve in the material of the finished product mechanical strength comparable to the strength of materials obtained by traditional technologies (in particular, hot rolling technology). In particular, the possibility of complex parts manufacturing, a turbine blade with a given structure of the Inconel 718 alloy, namely, by SLS by varying the technological parameters of the process is described in [17]. The study of the structure and phase composition of the alloy Inconel 718 , obtained by 3D-printing with subsequent heat treatment, is devoted to [18]. The studies of the mechanical properties and structure of the Inconel 718 alloy, made by the SLS method or argon or nitrogen gas from pre-alloyed powder, are carried out in [19]. The authors of [20] paid attention to the comparative analysis of the mechanical properties of the Inconel 718 alloy with the properties of forged and cast material, which is obtained by the SLS method. In the work [21], a new method of forming 'programmed' mechanical properties in given parts of the part by controlling the microstructure of alloys in additive production is offered. A gradient material of heat-resistant Inconel 718 alloy with a large elongated grain in the core and a fine-grained microstructure in the outer shell, which has higher performance characteristics than the alloy made by traditional technology, is obtained. The authors of the work [22] represent the results of experimental and theoretical studies of the conditions for the formation of submicrocrystalline structure in billets made of Inconel 718 alloy. It is shown that the crushing of structural elements of alloys while maintaining the integrity of the workpiece is possible in a narrow temperature range.

\section{EXPERIMENTAL DETAILS}

The possibility of manufacturing blanks by 3D-printing is performed on the installation 'EOS M400' from heat-resistant corrosion-resistant Inconel 718 nickel alloy (IN718) in the conditions of JSC 'Motor Sich'. Powders of the company 'LPW' (Great Britain) are used as initial materials.

The samples received for the study are subjected to hot isostatic pressing with subsequent heat treatment, in accordance with the requirements of the technical conditions for aerospace materials ASM $5662 \mathrm{M}$.

The HIP process is performed according to the following mode:

- initial pressure $-25( \pm 5) \mathrm{MPa}$;

- heating at a speed of $8-10^{\circ} \mathrm{C} / \mathrm{min}$ to a temperature of $1040( \pm 10)^{\circ} \mathrm{C}$ (exposure 1 hour), working pressure in a high pressure vessel of 120 
$\mathrm{MPa}$;

- heating at a rate of $3-5{ }^{\circ} \mathrm{C} / \mathrm{min}$ to a temperature of $1150( \pm 10)^{\circ} \mathrm{C}$ (exposure $3-4$ hours), the working pressure in the high pressure vessel $160 \mathrm{MPa}$;

- cooling rate to a temperature of $800^{\circ} \mathrm{C} \rightarrow 60-100 \%$, further-not regulated.

Heat treatment after HIP surgery is performed in a dynamic vacuum according to the following mode:

- annealing to a solid solution under the influence of temperature $954^{\circ} \mathrm{C}$ for 1 hour at a thickness of $25 \mathrm{~mm} \rightarrow$ cooling in a stream of argon;

- aging at a temperature of $718^{\circ} \mathrm{C}$ for 8 hours $\rightarrow$ slow cooling in the furnace to a temperature of $621^{\circ} \mathrm{C}$ for a total hardening time of 18 hours $\rightarrow$ cooling in a stream of argon.

The chemical composition of the alloy Inconel 718 is determined by spectral and chemical analysis.

To determine the mechanical properties, samples of both cylindrical $(\varnothing 14 \mathrm{~mm}$ ) and rectangular (with a cross section of $16 \mathrm{~mm}$ ) shape are made.

The mechanical properties of the Inconel 718 alloy determined:

1. In the horizontal direction $X Y$ :

- No. H1-H3-cylindrical specimens after tensile tests;

- No. H1-H3 - rectangular samples after toughness tests;

- No. H4-H6 - cylindrical sample after long-term durability tests;

2. In the vertical direction $Z$ :

- No. V1-V3-cylindrical specimens after tensile tests;

- No. V1-V3-rectangular samples after toughness tests;

- No. V4-V6-cylindrical sample after long-term durability tests.

The long-term durability of the samples is determined on an Instron M3 at temperature of $800^{\circ} \mathrm{C}$ and constant applied load of $206 \mathrm{MPa}$. When tested for long-term durability, the samples are brought to fracture.

The ultimate stress $\left(\sigma_{u}\right), 0.2 \%$ proof stress $\left(\sigma_{0.2}\right)$, relative extension $(\delta)$ and relative narrowing $(\psi)$ of the samples are tested on a ZDMY30 bursting machine.

The toughness $(K C U)$ is determined on impact samples with a concentrator of type $U$, tested on a pendulum dill Instron SI-1 M. The Young's modulus $(E)$ is determined according to GOST 25095-82. Hardness is determined on a LECO AMH-43 Brinell hardness tester according to DSTU EN ISO 6506-1: 2019.

The mechanical properties of Inconel 718 alloy are determined at room temperature $\left(20^{\circ} \mathrm{C}\right)$, and heat-resistant-at a temperature of $650^{\circ} \mathrm{C}$ and applied load of $687 \mathrm{MPa}$.

Studies of the macrostructure and microstructure are performed on undigested sections on a microscope 'Axio Observer. Dlm'. 


\section{RESULTS AND DISCUSSION}

Studies of the chemical composition (Table 1) of the heat-resistant Inconel 718 alloy, obtained by SLS from powder produced by 'LPW' (UK), showed compliance with ASM 5662M for alloy Inconel 718 and standards TU 14-1-3905-85 for similar $\mathrm{Ni}-\mathrm{Fe}-\mathrm{Cr}$ deformed alloy EP718-VD (ID) (HN45MVTYUBR), which is designed for the manufacture of high-load parts of the hot part of gas turbine engines operating at temperatures up to $700^{\circ} \mathrm{C}$.

Analysis of the mechanical properties of the Inconel 718 alloy (Table 2) from the direction of growth of the part (horizontal direction $X Y$

TABLE 1. The chemical composition of the alloy Inconel 718, obtained from powder produced by the company 'LPW', and according to AMS 5662M.

\begin{tabular}{|c|c|c|c|c|c|c|c|c|c|c|c|c|}
\hline \multirow{2}{*}{$\begin{array}{c}\text { Inconel } \\
718 \text { Alloy }\end{array}$} & \multicolumn{12}{|c|}{ The content of the elements, $\%$} \\
\hline & $\mathrm{C}$ & $\mathrm{Cr}$ & $\mathrm{Ni}$ & $\mathrm{Al}$ & $\mathrm{Ti}$ & Mo & $\mathrm{Nb}$ & $\mathrm{Mn}$ & $\mathrm{Si}$ & B & $\mathrm{S}$ & $\mathrm{P}$ \\
\hline $\begin{array}{l}\text { Powder of } \\
\text { the Com- } \\
\text { pany } \\
\text { 'LPW' }\end{array}$ & 0.07 & 18.7 & 52.5 & 0.61 & 0.90 & 2.91 & 5.33 & $<0.1$ & $<0.1$ & $<0.006$ & $<0.0$ & 06 \\
\hline $\begin{array}{l}\text { Norms } \\
\text { AMS } \\
5662 \mathrm{M}\end{array}$ & $\leq 0.08$ & $\begin{array}{c}17.0- \\
21.0\end{array}$ & $\begin{array}{c}50.0- \\
55.0\end{array}$ & $\begin{array}{c}0.2- \\
0.8\end{array}$ & $\begin{array}{c}0.65- \\
1.15\end{array}$ & $\begin{array}{c}2.8- \\
3.3\end{array}$ & $\begin{array}{c}4.75- \\
5.5\end{array}$ & $\leq 0.35$ & $\leq 0.35$ & $\leq 0.006$ & $\leq 0.0$ & 15 \\
\hline
\end{tabular}

TABLE 2. Mechanical properties of samples made of Inconel 718 alloy.

\begin{tabular}{|c|c|c|c|c|c|c|c|c|c|}
\hline \multirow[b]{2}{*}{$\begin{array}{c}\text { Directions of } \\
\text { sample con- } \\
\text { struction }\end{array}$} & \multirow[b]{2}{*}{$\begin{array}{l}\text { No. of } \\
\text { sample }\end{array}$} & \multicolumn{8}{|c|}{ Mechanical properties at $20^{\circ} \mathrm{C}$} \\
\hline & & $\begin{array}{c}\sigma_{u} \\
\mathrm{MPa}\end{array}$ & $\begin{array}{l}\sigma_{0,2} \\
\mathrm{MPa}\end{array}$ & $\begin{array}{l}\delta \\
\%\end{array}$ & $\begin{array}{l}\psi, \\
\%\end{array}$ & $\begin{array}{l}K C U \\
\mathrm{~kJ} / \mathrm{m}^{2}\end{array}$ & $\begin{array}{c}E, \\
\mathrm{GPa}\end{array}$ & $\begin{array}{c}\text { Brinell } \\
\text { hard- } \\
\text { ness, } \\
H B\end{array}$ & $\begin{array}{c}d_{\mathrm{imp}} \\
\mathrm{mm}\end{array}$ \\
\hline \multirow{3}{*}{$\begin{array}{c}\text { Horizontal } \\
\qquad X Y\end{array}$} & H1 & 1359 & 1066 & 22 & 32.8 & 5.0 & 284.94 & 401 & 3.05 \\
\hline & $\mathrm{H} 2$ & 1364 & 1156 & 18 & 29.5 & 5.0 & 309.89 & 388 & 3.10 \\
\hline & H3 & 1362 & 1153 & 20 & 29.2 & 5.0 & 317.01 & 388 & 3.10 \\
\hline \multirow[t]{2}{*}{ Norms of AM } & $\mathrm{S} 5662 \mathrm{M}$ & $\geq 1251$ & $\geq 1014$ & $\geq 12$ & $\geq 15,0$ & - & - & $\geq 331$ & $\leq 3.35$ \\
\hline & $\mathrm{V} 1$ & 1340 & 1131 & 22 & 29.2 & 5.1 & 352.50 & 388 & 3.10 \\
\hline \multirow[t]{2}{*}{ Vertical $Z$} & $\mathrm{~V} 2$ & 1338 & 1139 & 18 & 26.0 & 6.8 & 282.72 & 401 & 3.05 \\
\hline & V3 & 1339 & 1129 & 18 & 32.5 & 5.5 & 294.86 & 338 & 3.10 \\
\hline \multicolumn{2}{|c|}{ Norms of AMS 5662M } & $\geq 1217$ & $\geq 1014$ & $\geq 10$ & $\geq 12.0$ & - & - & $\geq 331$ & $\leq 3.35$ \\
\hline \multicolumn{2}{|c|}{$\begin{array}{c}\text { Norms of TU 14-1- } \\
3905-85 \text { (longitudinal) }\end{array}$} & $\geq 1128$ & $\geq 687$ & $\geq 12$ & $\geq 14.0$ & $\geq 3.5$ & 196.13 & $\begin{array}{c}363- \\
293\end{array}$ & $\begin{array}{c}3.20- \\
3.55\end{array}$ \\
\hline
\end{tabular}


TABLE 3. Heat-resistant properties of samples from Inconel 718 alloy.

\begin{tabular}{|c|c|c|c|c|}
\hline \multirow{2}{*}{$\begin{array}{l}\text { Directions of sam- } \\
\text { ple construction }\end{array}$} & \multirow[b]{2}{*}{ No. of sample } & \multicolumn{3}{|c|}{ Long-term durability } \\
\hline & & $\begin{array}{c}\text { Temperature } \\
\text { testing, }{ }^{\circ} \mathrm{C}\end{array}$ & $\begin{array}{c}\text { Applied load, } \\
\mathrm{MPa}\end{array}$ & $\begin{array}{l}\text { Time to frac- } \\
\text { ture, } h\end{array}$ \\
\hline \multirow{3}{*}{ Horizontal $X Y$} & $\mathrm{H} 4$ & 650 & 687 & 142.00 \\
\hline & H5 & 650 & 687 & 109.00 \\
\hline & H6 & 650 & 687 & 127.75 \\
\hline \multirow{3}{*}{ Vertical $Z$} & V4 & 650 & 687 & 87.50 \\
\hline & V5 & 650 & 687 & 121.50 \\
\hline & V6 & 650 & 687 & 129.00 \\
\hline \multicolumn{2}{|c|}{ Norms of AMS 5662M } & 650 & 687 & $\geq 23.00$ \\
\hline \multicolumn{2}{|c|}{$\begin{array}{c}\text { Norms of TU 14-1-3905-85 } \\
\text { (longitudinal) }\end{array}$} & 600 & 785 & $\geq 60.00$ \\
\hline
\end{tabular}

and vertical direction $Z$ ) with the normative characteristics of ASM $5662 \mathrm{M}$ and TU 14-1-3905-85 showed a significant excess of the requirements for rods of deformable alloy EP718-VD (ID). Moreover, comparing the mechanical properties from the direction of growth of the part, it is found that for horizontal samples the values of $\sigma_{u}$ are $1.6 \%, \delta 3.5 \%$ and $\psi 4.3 \%$ higher than vertical samples. The values of $\sigma_{0.2}, K C U$ and $E$ for horizontal samples on the contrary are lower than vertical samples by $0.7 \%, 16 \%$, and $2 \%$, respectively. It is shown that for horizontal and vertical samples the Brinell hardness and diameter of the impression are the same and average $392 \mathrm{HB}$ and $3.08 \mathrm{~mm}$, respectively.

The heat-resistant properties of cylindrical heat-treated samples of Inconel 718 alloy grown in both the horizontal direction $X Y$ and the vertical direction $Z$ (Table 3) also meet the standards of AMS 5662M: the time to fracture $\approx 4.5$ times higher than the norms of AMS $5662 \mathrm{M}$, when this value of long-term durability of horizontal samples is $\approx 10 \%$ higher than vertical samples.

The state analysis of fractures after the destruction of rupture and impact samples from the alloy Inconel 718, grown both in the horizontal direction $X Y$ and in the vertical direction $Z$, showed that their structure is fine-grained (Figs. 1-3). On the samples grown in the $X Y$ direction, the structural orientation is traced at the fractures (longitudinal section) (Fig. 1, $b$ shows a black arrow).

The macrostructure of the samples grown by the SLS method, after the HIP followed by heat treatment, is dense, homogeneous and characterized by a fine-grained structure. It is established that the macrograins in the structure of the samples are elongated in the direction of growth of the samples (Figs. 4 and 5). 


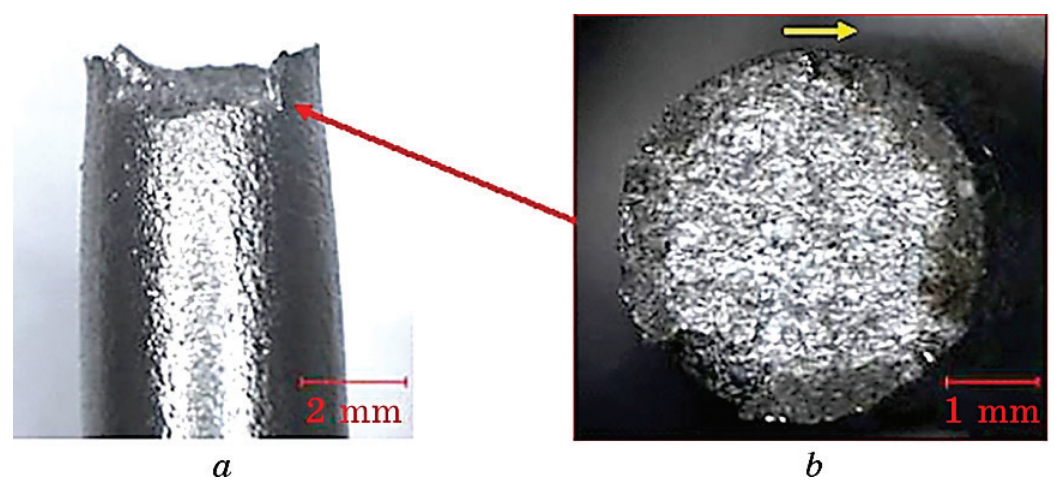

Fig. 1. Fracture zone $(a)$ and fracture structure $(b)$ of rupture sample No. H1 from Inconel 718 alloy grown in $X Y$ direction, after heat treatment, $\times 10$.

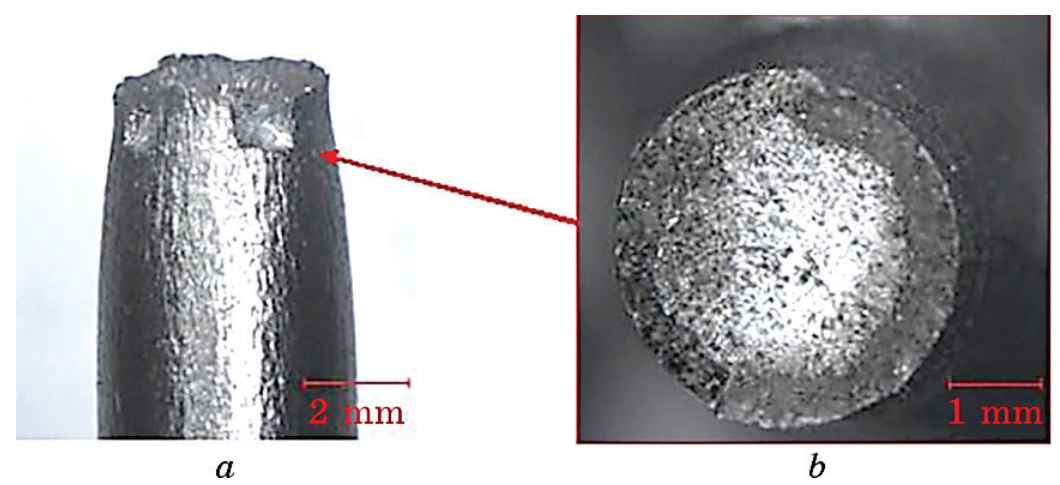

Fig. 2. Fracture zone $(a)$ and fracture structure $(b)$ of rupture sample No. V1 from Inconel 718 alloy grown in the $Z$ direction, after heat treatment, $\times 10$.

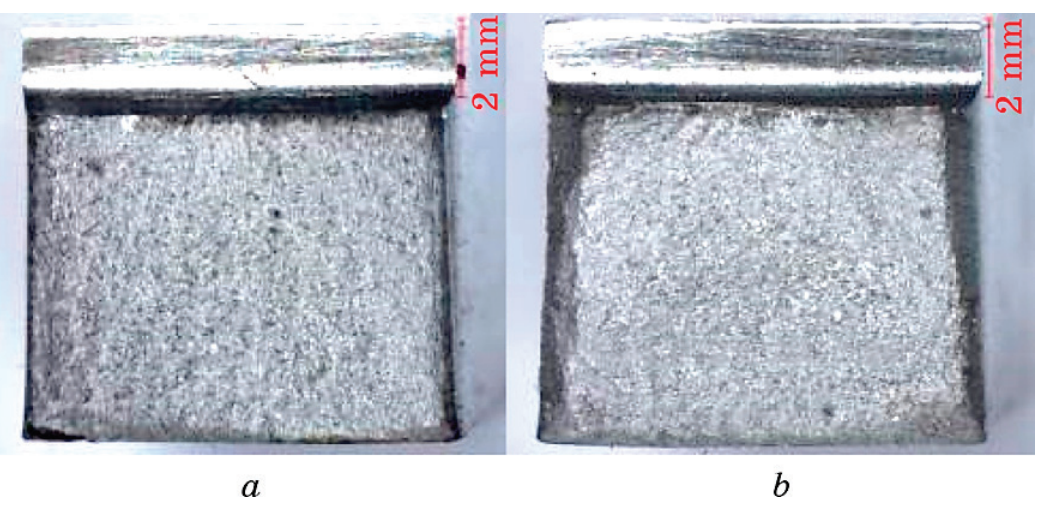

Fig. 3. The structure of the impact fracture of the alloy Inconel 718, grown by the SLS method, $\times 6.5: a$-sample No. H3; $b$-sample No. V3. 


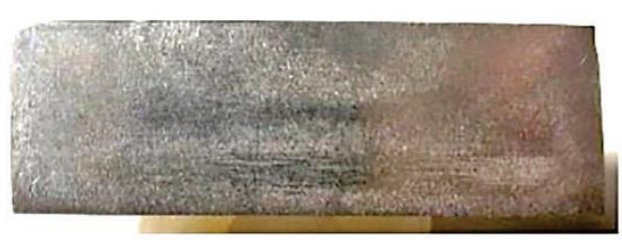

$a$

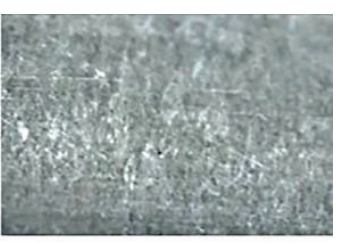

$b$

Fig. 4. The macrostructure of the sample No. H3 grown in the $X Y$ direction by the SLS method from the alloy Inconel 718 (longitudinal section of the impact sample).

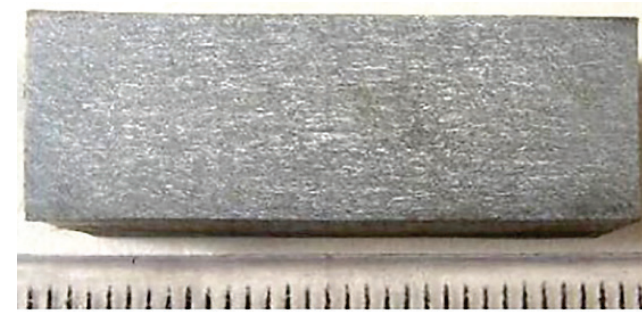

$a$

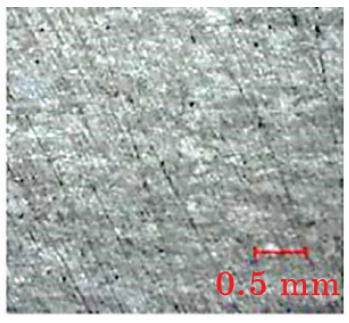

$b$

Fig. 5. The macrostructure of the sample No. V2 grown in the $Z$ direction by the SLS method from the alloy Inconel 718 (longitudinal section of the impact sample).
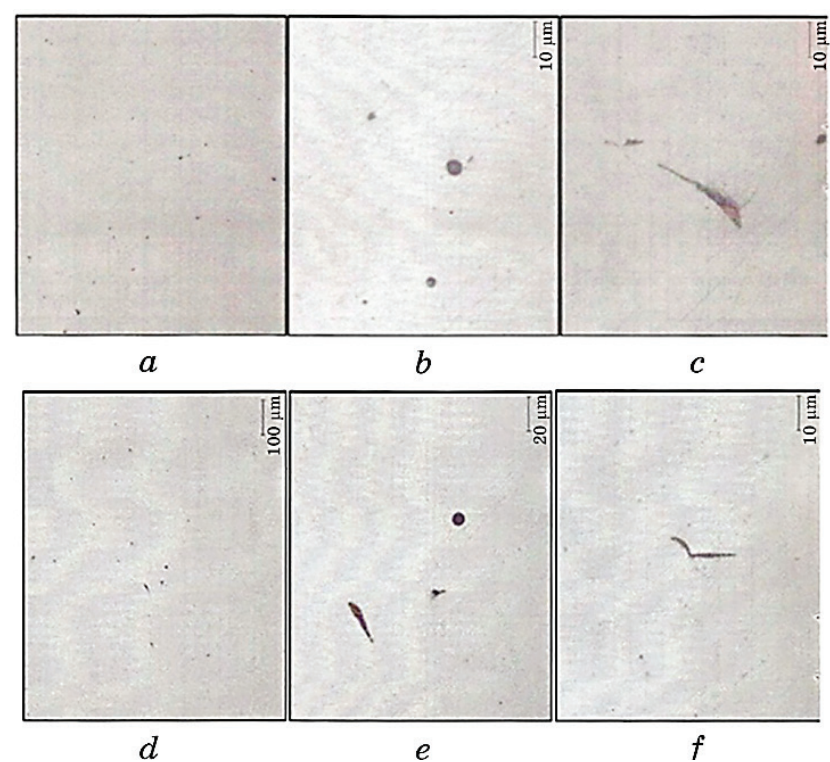

Fig. 6. Oxides in the 'healing' zones in samples No. H2 $(a, b, c)$ and No. V3 ( $d$, $e, f)$ grown by SLS from Inconel 718 alloy (HIP + heat treatment): $a-c-$ sample No. H2 at magnification $\times 100, \times 500, \times 1000$, respectively; $d-f-$ sample No. V3 at magnification $\times 100, \times 500, \times 1000$, respectively. 


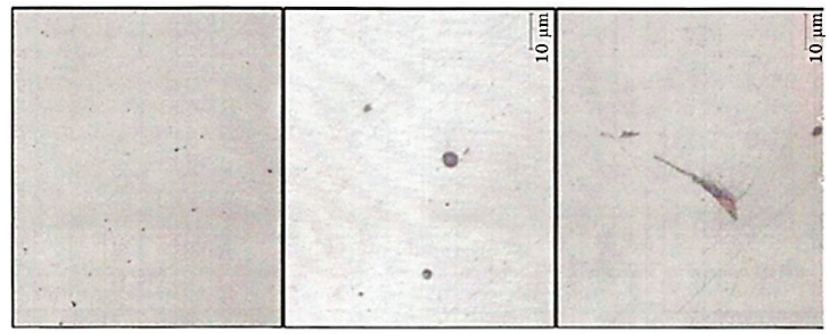

$a$

$b$

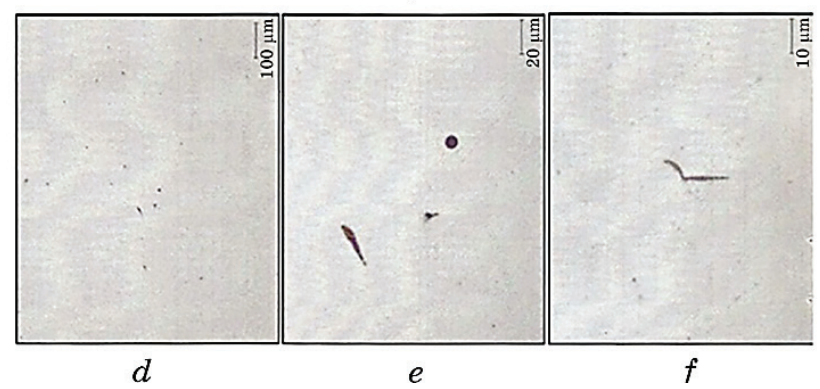

Fig. 6. Oxides in the 'healing' zones in samples No. H2 $(a, b, c)$ and No. V3 ( $d$, $e, f$ ) grown by SLS from Inconel 718 alloy (HIP + heat treatment): $a-c-$ sample No. H2 at magnification $\times 100, \times 500, \times 1000$, respectively; $d-f-$ sample No. V3 at magnification $\times 100, \times 500, \times 1000$, respectively.

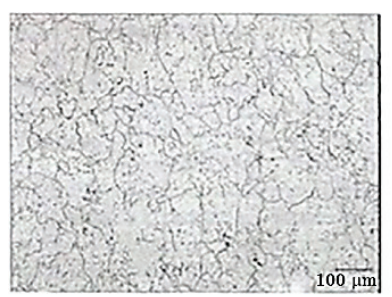

$a$

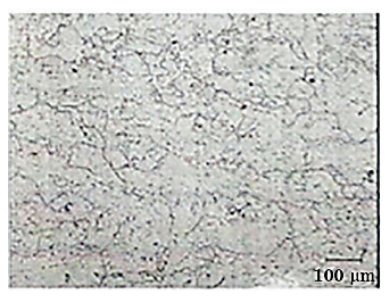

$c$

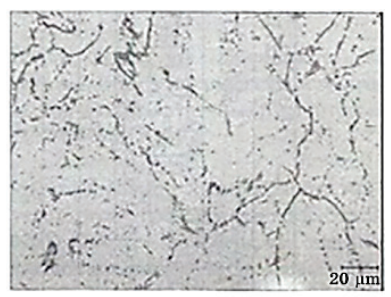

$b$

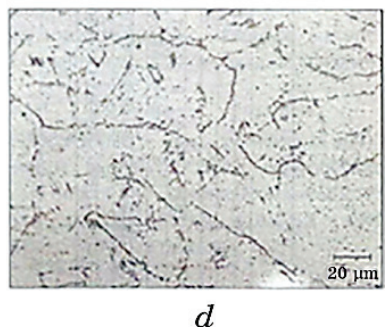

Fig. 7. Microstructure of samples grown by SLS from Inconel 718 alloy (HIP + + heat treatment): $a$-sample No. H2, $\times 100 ; b$-sample No. H2, $\times 500 ; c-$ sample No. V3, $\times 100 ; d-$ sample No. V3, $\times 500$. 

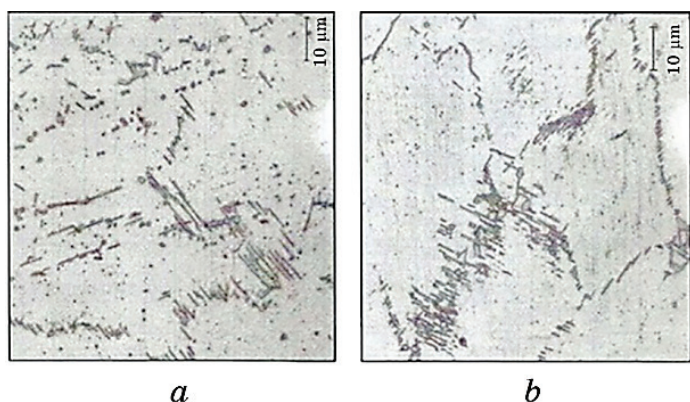

Fig. 8. Microstructure of the plate-phase in samples grown by SLS from Inconel 718 alloy (HIP + heat treatment): $a$-sample No. H2, $\times 1000 ; b$-sample No. V3, $\times 1000$.

Metallographic studies have shown that the operation of the HIP followed by heat treatment contributes to almost complete 'healing' of pores and microdiscontinuities, which are concentrated in the internal volumes of metal, while in the areas of 'healing' revealed globular and (or) film oxides (Fig. 6).

The microstructure of the samples grown in both the horizontal $X Y$ direction and the vertical $Z$ direction is characteristic of the normal heat-treated state of the Inconel 718 alloy, with no overheating observed (Fig. 7). In the material of the studied samples after HIP with the subsequent heat treatment there is a release of a lamellar $\delta$-phase (Fig. 8), thus carbides and carbonitrides are allocated generally in the form of discrete globular particles.

\section{CONCLUSION}

1. The mechanical properties of the heat-resistant Inconel 718 alloy, obtained by the SLS method on the installation 'EOS M400' from powders of 'LPW' (Great Britain), both in the horizontal direction XY and in the vertical direction $Z$, meet the regulatory characteristics of ASM $5662 \mathrm{M}$ for Inconel alloy 718 and exceed the norms of TU 14-1-3905-85 for alloy EP718-VD (ID).

2. The heat-resistant properties of heat-treated samples of Inconel 718 alloy grown in both the horizontal direction $X Y$ and the vertical direction $Z$ meet the standards of ASM $5662 \mathrm{M}$, while the values of longterm durability of horizontal samples are $\approx 10 \%$ higher than vertical samples.

3. The macrostructure of heat-treated samples of Inconel 718 alloy grown by SLS from 'LPW' powders (along the impact sample) is dense, homogeneous and characterized by a fine-grained structure.

4. It is established that hot isostatic pressing followed by heat treat- 
ment promotes almost complete 'healing' of pores and microdiscontinuities, which are concentrated in the internal volumes of metal, while globular and (or) film oxides are detected in the 'healing' zones.

5 . The microstructure of the samples grown in both the horizontal direction $X Y$ and the vertical direction $Z$, is characteristic of the normal heat-treated state of the alloy Inconel 718, with no overheating is observed. In the material of the test samples after hot isostatic pressing followed by heat treatment there is a selection of lamellar $\delta$-phases, with carbides and carbonitrides are released mainly in the form of discrete globular particles.

\section{REFERENCES}

1. B. Graf, S. Gook, A. Gumenyuk, and M. Rethmeier, Global Nuclear Safety, No. 3(20): 110 (2016).

2. A. S. Vehov and S. A Titarenko, Reshetnevskie Chteniya, 1, No. 22: 645 (2018) (in Russian).

3. A. V. Balaykin, V. G. Smelov, and L. A. Chempinskiy, Vestnik Samarskogo Gosudarstvennogo Aerokosmicheskogo Universiteta im. Akademika S. P. Korolyova, No. 3-2(34): 380 (2012) (in Russian).

4. O. S. Vodennikova, Materialy Mizhnarodnoyi Naukovo-Praktychnoyi Konferentsiyi 'Formuvannya Kontseptsiyi Tsyfrovizatsiyi Yak Chynnyk Rozvytku Kreatyvnosti Osobystosti ta Yiyi Vplyv na Rozvytok Lyudskoho yi Sotsialnoho Kapitalu' [Proceedings of the International Scientific-Practical Conference 'Formation of the Concept of Digitalization as a Factor in the Development of Personal Creativity and Its Impact on the Development of Human and Social Capital'] (Nov. 26-27, 2020) (Zaporizhzhia: ZNU: 2020), p. 290 (in Ukrainian).

5. B. Lu, D. Li, and X. Tian, Engineering, Iss. 1, No. 1: 85 (2015).

6. A. Popovich, V. Sufiiarov, I. Polozov, E. Borisov, and D. Masaylo, Proceedings of the 25th Anniversary International Conference on Metallurgy and Materials 'METAL 2016' (2016), p. 1504.

7. A. D. Leonenkov and V. V. Dvirny, Reshetnevskie Chteniya, 2, No. 2: 759 (2017) (in Russian).

8. ASM Metals HandBook Properties and Selection: Nonferrous Alloys and Special-Purpose Materials (ASM International: 2002), vol. 2.

9. M. V. Andrievskij, M. A. Mitikov, S. V. Adzhamskij, and D. A. Shamrovskij, Aviatsionno-Kosmicheskaya Tekhnika i Tekhnologiya, No. 6(141): 112 (2017).

10. S. V. Adzhamskiy, Aerospace Technic and Technology, No. 2(154): 86 (2019) (in Russian).

11. V.Sh. Sufiyarov, A. A. Popovich, E. V. Borisov, and I. A. Polozov, Tsvetnye Metally, No. 1: 97 (2015) (in Russian).

12. K. Sh. Mukhtarova, and R. V. Shakhov, Kaybyshevskie Chteniya: Sbornik Dokladov I Mezhvuzovskoy Molodezhnoy Nauchnoy Shkoly-Konferentsii [Kaibyshev Readings: Collection of Reports of the I Interuniversity Youth Scientific School-Conference] (April 25, 2018, Ufa), p. 127 (in Russian).

13. M. O. Dmitrieva, A. A. Mel'nikov, A. M. Golovach, O. S. Bondareva, V. G. Smelov, A. V. Sotov, and A. V. Agapovichev, Vektor Nauki 
Tolyatinskogo Gosudarstvennogo Universiteta, No. 1(51): 92 (2020) (in Russian).

14. A. A. Pedash, V. V. Klochikhin, N. A. Lysenko, V. G. Shilo, and P. A. Kasai, Vestnik Dvigatelestroeniya, No. 2: 175 (2019) (in Russian).

15. A. A. Pedash, N. A. Lyasenko, V. V. Klochixin, and V. G. Shilo, Aerospace Technic and Technology, No. 8(143): 145 (2017) (in Russian).

16. M. Yu. Gryaznov, S. V. Shotin, and V. N. Chuvildeev, Vestnik Nizhegorodskogo Gosuniversiteta im. N. I. Lobachevskogo, No. 4(1): 508 (2014) (in Russian).

17. V. E. Borisov, Formirovanie Zadannoy Struktury Turbinnoy Lopatki iz Zharoprochnogo Nikelevogo Splava Metodom Selektivnogo Lazernogo Plavleniya [Formation of a Given Structure of a Turbine Blade from a Heat-Resistant Nickel Alloy by the Method of Selective Laser Melting] (Disser. for Cand. Tech. Sci) (St. Petersburg: Federal State Autonomous Educational Institution of Higher Education 'Peter the Great St. Petersburg Polytechnic University': 2017) (in Russian).

18. A. Mostafa, I. P. Rubio, V. Brailovski, M. Jahazi, and M. Medraj, Metals, 7: 196 (2017).

19. K. N. Amato, S. M. Gaytan, L. E. Murr, E. Martinez, P. W. Shindo, J. Hernandez, S. Collins, and F. Medina, Acta Mater., 60(5): 2448 (2012).

20. T. Trosch., J. Strobner, R. Volkl, and U. Glatzel, Mater. Lett., 164: 664 (2016).

21. V. A. Popovich, E. V. Borisov, V. Sh. Sufiyarov, and A. A. Popovich, Metallovedenie i Termicheskaya Obrabotka, No. 11 (761): 70 (2018) (in Russian).

22. D. V. Pavlenko, V. Yu. Kotsjuba, and S. N. Paholka, Aerospace Technic and Technology, No. 10(127): 33 (2015) (in Russian). 